Int. J. Electrochem. Sci., 14 (2019) 8131 - 8140

International Journal of

ELECTROCHEMICAL

SCIENCE

www.electrochemsci.org

\title{
$d s$ DNA Sensing Capabilities of Metallopolymers Electrochemically Deposited from Ruthenium-Pyrrole and - Thiophene Complexes
}

\author{
M. A. de Valle, ${ }^{1, *}$ B. González ${ }^{1}$, C. Espinosa-Bustos ${ }^{2}$, A. M. R. Ramírez ${ }^{3}$, M. Gacitúa ${ }^{4}$, \\ L. A. Hernández, ${ }^{5, *}$ \\ ${ }^{1}$ Pontificia Universidad Católica de Chile, Laboratorio de Electroquímica de Polímeros (LEP), Av. V. \\ Mackenna 4860, 7820436-Macul, Santiago, Chile. \\ ${ }^{2}$ Pontificia Universidad Católica de Chile, Departamento de Farmacia, Av. V. Mackenna 4860, \\ 7820436-Macul, Santiago, Chile. \\ ${ }^{3}$ Universidad Mayor, Núcleo Química y Bioquímica, Facultad de Estudios Interdisciplinarios, \\ Laboratorio de Electroquímica, Av. Alemania 0281, 4801043-Temuco, Chile. \\ ${ }^{4}$ Universidad de Santiago de Chile, Facultad de Química y Biología,. Av. L.B. O’Higgins 3363, \\ Santiago, 7254758, Chile. \\ ${ }^{5}$ Universidad de Valparaíso, Facultad de Ciencias, Instituto de Química y Bioquímica, Laboratorio de \\ Electroquímica, Avda. Gran Bretaña 1111, Valparaíso, Chile. \\ *E-mail: mdvalle@uc.cl, loreto.hernandez@uv.cl
}

doi: $10.20964 / 2019.08 .64$

Received: 25 March 2019 / Accepted: 11 June 2019 / Published: 30 June 2019

In the current work, a study is presented based on the variation of the monomer unit (thiophene or pyrrole) at electrochemically polymerizable ruthenium complexes, evaluating their possible applications in the field of biosensors to detect $d s \mathrm{DNA}$. For both complexes $([\mathrm{Ru}(\mathrm{p}-$ cymene $\left.)\left(\mathrm{C}_{4} \mathrm{H}_{4} \mathrm{~S}\right)_{2}\right]^{2+}$ and $\left.\left[\mathrm{Ru}(\mathrm{p} \text {-cymene })\left(\mathrm{C}_{5} \mathrm{H}_{4} \mathrm{NH}\right)_{2}\right]^{2+}\right)$, the metallopolymer is deposited on platinum electrodes displaying voltamperometric responses consistent with expected polymer including the corresponding $\mathrm{Ru}^{\mathrm{III} \rightarrow \mathrm{II}}$ redox signa. The subsequent evaluation of these electrodeposits, in the presence and absence of $d s \mathrm{DNA}$, demonstrated the essential role that monomer play when an application of these modified electrodes is needed. The use of thiophene as a polymerizable produces a more intense analyte-electrode interaction, with an electrode about 1.7 more sensitive to $d s$ DNA compared to that of pyrrole.

Keywords: conducting metallopolymers; poly(thiophene); poly(pyrrole); ruthenium complexes; modified electrodes; $d s$ DNA. 


\section{FULL TEXT}

(C) 2019 The Authors. Published by ESG (www.electrochemsci.org). This article is an open access article distributed under the terms and conditions of the Creative Commons Attribution license (http://creativecommons.org/licenses/by/4.0/). 